ҚАЗАҚСТАН РЕСПУБЛИКАСЫ

ҰЛТТЫҚ ҒЫЛЫМ АКАДЕМИЯСЫНЫН

АБАЙ АТЫНДАҒЫ ҚАЗАҚ ҰЛТТЫҚ

ПЕДАГОГИКАЛЫҚ УНИВЕРСИТЕТІНІҢ

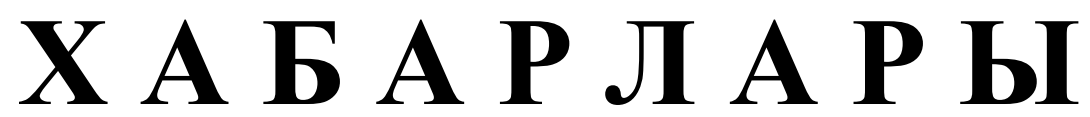

\section{ИЗВЕСТИЯ}

НАЦИОНАЛЬНОЙ АКАДЕМИИ НАУК РЕСПУБЛИКИ КАЗАХСТАН

КАЗАХСКИЙ НАЦИОНАЛЬНЫЙ

ПЕДАГОГИЧЕСКИЙ УНИВЕРСИТЕТ ИМ. АБАЯ

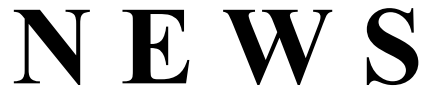

OF THE NATIONAL ACADEMY OF SCIENCES OF THE REPUBLIC OF KAZAKHSTAN

ABAY KAZAKH NATIONAL PEDAGOGICAL UNIVERSITY

ҚОҒАМДЫҚ ЖӘНЕ ГУМАНИТАРЛЫҚ ҒЫЛЫМДАР СЕРИЯСЫ

СЕРИЯ ОБЩЕСТВЕННЫХ И ГУМАНИТАРНЫХ НАУК

SERIES OF SOCIAL AND HUMAN SCIENCES

\author{
6 (322) \\ ҚАРАША - ЖЕЛТОҚСАН 2018 ж. \\ НОЯБРЬ - ДЕКАБРЬ 2018 Г. \\ NOVEMBER - DECEMBER 2018 \\ ИЗДАЕТСЯ С ЯНВАРЯ 1962 ГОДА \\ PUBLISHED SINCE JANUARY 1962 \\ ЖЫЛЫНА 6 РЕТ ШЫҒАДЫ \\ ВЫХОДИТ 6 РАЗ В ГОД \\ PUBLISHED 6 TIMES A YEAR
}

1962 ЖЫЛДЫҢ ҚАНТАР АЙЫНАН ШЫҒА БАСТАҒАН 
Ба с ре дактор

ҚР ҰҒА кұрметті мүшесі

Балықбаев Т.O.

Р е д а ц и я а лқ а сы:

экон. ғ. докторы, проф., ҚР ҰҒА академигі Баймұратов У.Б.; тарих ғ. докторы, проф., ҚР ҰҒА академигі Байпақов К.М.; филос. ғ.докторы, проф., ҚР ҰҒА академигі Есім Г.Е.; фил. ғ. докторы,, проф., ҚР ҰҒА академигі Қирабаев С.С.; эк. ғ. докторы, проф., ҚР ҰҒА академигі Кошанов А.К.; эк.ғ. докторы, проф., ҚР ҰҒА академигі Нәрібаев К.Н. (бас редактордың орынбасары); филос. ғ.докторы, проф., ҚР ҰҒА академигі Нысанбаев А.Н.; заң ғ. докторы, проф., ҚР ҰҒА академигі Сәбікенов С.Н.; заң ғ. докторы, проф., ҚР ҰҒА академигі Сүлейменов М.К.; эк. ғ. докторы, проф., ҚР ҰҒА академигі Сатыбалдин С.С.; тарих ғ. докторы, проф., ҚР ҰҒА академик Әбжанов Х.М.; тарих ғ. докторы, проф., ҚР ҰҒА корр. мүшесі Әбусеитова М.Х.; тарих ғ. докторы, проф., ҚР ҰҒА академик Байтанаев Б.А.; филол. ғ. докторы, проф., ҚР ҰҒА корр. мүшесі Жақып Б.А.; фил. ғ. докторы, проф., академик НАН РК Қалижанов У.К.; филол. ғ. докторы, проф., ҚР ҰҒА академик Қамзабекұлы Д.; тарих ғ. докторы, проф., ҚР ҰҒА академик Қожамжарова Д.П.; тарих ғ. докторы, проф., ҚР ҰҒА академик Койгелдиев М.К.; фил. ғ. докторы, проф., ҚР ҰҒА корр. мүшесі Кұрманбайұлы Ш.; тарих ғ. докторы, проф., ҚР ҰҒА корр. мүшесі Таймағанбетов Ж.К.; социол. ғ. докторы, проф., ҚР ҰҒА корр. мүшесі Шәукенова 3.К.; фил. ғ. докторы, проф., КР ҰҒА корр. мүшесі Дербісәлі А.; саяси. ғ. докторы, проф., Бижанов А.К., тарих ғ. докторы, проф., Кабульдинов 3.Е.; фил. ғ. докторы, проф., ҚР ҰҒА корр мүшесі Қажыбек Е.3.

\section{Р едакция ке н е с i:}

Молдова Республикасының ҰҒА академигі Белостечник Г. (Молдова); Әзірбайжан ҰҒА академигі Велиханлы Н. (Азербайджан); Тәжікстан ҰҒА академигі Назаров Т.Н. (Тәжікстан); Молдова Республикасының ҰҒА академигі Рошка А. (Молдова); Молдова Республикасының ҰҒА академигі Руснак Г. (Молдова); Әзірбайжан ҰҒА корр. мүшесі Мурадов Ш. (Әзірбайжан); Әзірбайжан ҰҒА корр. мүшесі Сафарова 3. (Әзірбайжан); э. ғ. д., проф. Василенко В.Н. (Украина); заң ғ. докт., проф. Устименко В.А. (Украина)

«Қазақстан Республикасы Ұлттық ғылым академиясының Хабарлары. Қоғамдық және гуманитарлық ғылымдар сериясы». ISSN 2224-5294

Меншіктенуші: «Қазақстан Республикасының Ұлттық ғылым академиясы» РҚБ (Алматы қ.)

Қазақстан республикасының Мәдениет пен ақпарат министрлігінің Ақпарат және мұрағат комитетінде 30.04.2010 ж. берілген № 10894-Ж мерзімдік басылым тіркеуіне қойылу туралы куәлік

Мерзімділігі: жылына 6 рет.

Тиражы: 500 дана.

Редакцияның мекенжайы: 050010, Алматы қ., Шевченко көш., 28, 219 бөл., 220, тел.: 272-13-19, 272-13-18, http://nauka-nanrk.kz. social-human.kz

(C) Қазақстан Республикасының Ұлттық ғылым академиясы, 2018

Типографияның мекенжайы: «Аруна» ЖК, Алматы қ., Муратбаева көш., 75. 
Главный редактор

Почетный член НАН РК

T.O. Балыкбаев

Р е дак ци онн а я коллег и я:

докт. экон. Н., проф., академик НАН РК У.Б. Баймуратов; докт. ист. н., проф., академик НАН РК К.М. Байпаков; докт. филос. Н., проф., академик НАН РК Г.Е. Есим; докт. фил. Н., проф., академик НАН РК С.С. Кирабаев; докт. экон. Н., проф., академик НАН РК А.К. Кошанов; докт. экон. Н., проф., академик НАН РК К.Н. Нарибаев (заместитель главного редактора); докт. филос. н., проф., академик НАН РК А.Н. Нысанбаев; докт. юр. Н., проф., академик НАН РК С.Н. Сабикенов; докт. юр. н., проф., академик НАН РК М.К. Сулейменов; докт. экон. Н., проф., академик НАН РК С.С. Сатубалдин; докт. ист. н., проф., академик НАН РК Х.М. Абжанов; докт. ист. н., проф., чл.-корр. НАН РК М.Х. Абусеитова; докт. ист. н., проф., академик НАН РК Б.А. Байтанаев; докт. фил. н., проф., чл.-корр. НАН РК Б.А. Жакып; докт. фиолол. н., проф., академик НАН РК У.К. Калижанов; докт. фил. н., проф., академик НАН РК Д. Камзабекулы; докт. ист. н., проф., академик НАН РК Д.П. Кожамжарова; докт. ист. н., проф., академик НАН РК М.К. Койгельдиев; докт. филол. н., проф., чл.-корр. НАН РК Ш. Курманбайулы; докт. ист. н., проф., чл.корр. НАН РК Ж.К. Таймаганбетов; докт. социол. н., проф., чл.-корр. НАН РК З.К. Шаукенова; д. филол. н., проф., чл.-корр. НАН РК А. Дербисали; доктор политических наук, проф., Бижанов А.К.; доктор ист. наук, проф., Кабульдинов 3.Е.; доктор филол. н., проф., член-корр. НАН РК Қажыбек Е.3.

Р е дак ци онны й с ов ет

академик НАН Республики Молдова Г. Белостечник (Молдова); академик НАН Азербайджанской Республики Н. Велиханлы (Азербайджан); академик НАН Республики Таджикистан Т.Н. Назаров (Таджикистан); академик НАН Республики Молдова А. Рошка (Молдова); академик НАН Республики Молдова Г. Руснак (Молдова); чл.-корр. НАН Азербайджанской Республики Ш. Мурадов (Азербайджан), член-корр. НАН Азербайджанской Республики 3.Сафарова (Азербайджан); д. э. н., проф. В.Н. Василенко (Украина); д.ю.н., проф. В.А. Устименко (Украина)

Известия Национальной академии наук Республики Казахстан. Серия общественных и гуманитарных наук. ISSN 2224-5294

Собственник: РОО «Национальная академия наук Республики Казахстан» (г. Алматы)

Свидетельство о постановке на учет периодического печатного издания в Комитете информации и архивов

Министерства культуры и информации Республики Казахстан № 10894-Ж, выданное 30.04.2010 г.

Периодичность 6 раз в год

Тираж: 500 экземпляров

Адрес редакции: 050010, г. Алматы, ул. Шевченко, 28, ком. 219, 220, тел. 272-13-19, 272-13-18, www:nauka-nanrk.kz / social-human.kz

(C) Национальная академия наук Республики Казахстан, 2018 г.

Адрес типографии: ИП «Аруна», г. Алматы, ул. Муратбаева, 75

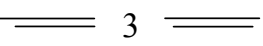


Chief Editor

\section{Honorary member of NAS RK \\ Balykbayev T.O}

Editorial board:

Doctor of economics, prof, academician of NAS RK Baimuratov U.B.; doctor of history, prof, academician of NAS RK Baipakov K.M.; doctor of philosophy, prof, academician of NAS RK Esim G.E.; doctor of philology, prof, academician of NAS RK Kirabayev S.S.; doctor of economics, prof, academician of NAS RK Koshanov A.K.; doctor of economics, prof, academician of NAS RK Naribayev K.N. (deputy editor-in-chief); doctor of philosophy, prof, academician of NAS RK Nyssanbayev A.N.; doctor of law, prof, academician of NAS RK Sabikenov S.N.; doctor of law, prof, academician of NAS RK Suleymenov M.K.; doctor of economy, prof, academician of NAS RK Satybaldin S.S.; doctor of history, prof, academician of NAS RK Abzhanov H.M; doctor of history, prof, corresponding member of NAS RK Abuseitova M.H.; doctor of history, prof, academician of NAS RK Baitanaev B.A.; doctor of philology, prof, corresponding member of NAS RK Zhakyp B.A.; doctor of philology, prof, academician of NAS RK Kalizhanov U.K.; doctor of philology, prof, academician of NAS RK Hamzabekuly D.; doctor of history, prof, academician of NAS RK Kozhamzharova D.P.; doctor of history, prof, academician of NAS RK Koigeldiev M.K.; doctor of philology, prof, corresponding member of NAS RK Kurmanbaiuly Sh.; doctor of history, prof, academician of NAS RK Taimaganbetov J.K.; doctor of sociology, prof, corresponding member of NAS RK Shaukenova Z.K.; doctor of philology, prof, corresponding member of NAS RK Derbisali A.; doctor of political science, prof Bizhanov A.K; doctor of History, prof Kabuldinov Z.E.; doctor of philology, prof, corresponding member of NAS RK Kazhybek E.Z.

\section{Editorial staff:}

Academician NAS Republic of Moldova Belostechnik.G (Moldova); Academician NAS Republic of Azerbaijan Velikhanli N. (Azerbaijan); Academician NAS Republic of Tajikistan Nazarov T.N. (Tajikistan); Academician NAS Republic of Moldova Roshka A. (Moldova) Academician NAS Republic of Moldova Rusnak G. (Moldova); Corresponding member of the NAS Republic of Azerbaijan Muradov Sh. (Azerbaijan); Corresponding member of the NAS Republic of Azerbaijan Safarova Z. (Azerbaijan); Associate professor of Economics Vasilenko V.N. (Ukraine), Associate professor of Law Ustimenko V.A. (Ukraine)

News of the National Academy of Sciences of the Republic of Kazakhstan. Series of Social and Humanities. ISSN 2224-5294

Owner: RPA "National Academy of Sciences of the Republic of Kazakhstan" (Almaty)

The certificate of registration of a periodic printed publication in the Committee of information and archives of the Ministry of culture and information of the Republic of Kazakhstan N 10894-Ж, issued 30.04.2010

Periodicity: 6 times a year

Circulation: 500 copies

Editorial address: 28, Shevchenko str., of. 219, 220, Almaty, 050010, tel. 272-13-19, 272-13-18, www:nauka-nanrk.kz / social-human.kz

(C) National Academy of Sciences of the Republic of Kazakhstan, 2018

Address of printing house: ST "Aruna", 75, Muratbayev str, Almaty 
N E W S

OF THE NATIONAL ACADEMY OF SCIENCES OF THE REPUBLIC OF KAZAKHSTAN

SERIES OF SOCIAL AND HUMAN SCIENCES

ISSN 2224-5294

https://doi.org/10.32014/2018.2224-5294.38

Volume 6, Number 322 (2018), 87 - 90

UDC 573.6

\author{
G.U.Abishova $^{1}$, R.A.Amanzholov ${ }^{1}$, B.N.Mynbayeva ${ }^{1}$, D.I. Ibragimova ${ }^{2}$ \\ ${ }^{1}$ Abai Kazakh national pedagogical university, Almaty, Kazakhstan; \\ ${ }^{2}$ A.Yassawi International Kazakh-Turkish University, Turkestan, Kazakhstan \\ abish.gul@mail.ru
}

\title{
READINESS OF STUDENTS-BIOLOGISTS FOR THE ORGANIZATION AND IMPLEMENTATION OF PROJECTS AT THE UNIVERSITY
}

\begin{abstract}
Today, reforms of the Kazakhstan education system are aimed at revising the system of requirements for knowledge, skills, abilities and personal qualities of a teacher from the position of a competence approach. In order to train students in the skills and abilities necessary for competitiveness in the global economy, it is necessary to implement project training or the project method. The readiness of biology students for the organization and implementation of projects is a prerequisite for the successful implementation of professional activities, since the ability to design contributes to the successful solution of professional tasks. Possessing enormous potential, the project activity allows to improve the quality of biological training of future specialists, educate the individual on the principles of unity of educational creativity with real practical activities.

In this article, to confirm the relevance of this study and clarify the state of the students' initial readiness to organize and implement projects at the university, a survey was conducted among bachelor students. The results of the survey indicate a low willingness of biology students to organize and implement projects and at the same time their high interest in learning project activities. Consequently, the project activities of students have to be formed both in the course of specially organized training and in the framework of academic subjects.

Keywords: project, project method, project activity, readiness, organization and implementation of projects, questionnaire survey.
\end{abstract}

1. Introduction. In the annual message of the President of the Republic of Kazakhstan, it is noted that curricula should be focused on the development of critical thinking abilities and self-searching skills [1-2]. The key priority of educational programs should be the development of the ability to continuously adapt to changes and assimilation of new knowledge [3].

One of the modern educational technologies that provides a rational combination of theoretical knowledge and its practical application to solve specific problems of reality is the technology of project learning (the so - called "project method"), the founder of which was an outstanding American philosopher and teacher John Dewey (1859-1952).

It should be noted that a significant number of works of Russian scientists are devoted to the study of the problem of project training in an university. But the analysis of literature also showed that in Kazakhstan relatively little attention is paid to solving this problem. To confirm the relevance of this study, it is necessary to find out the state of readiness of students to organize and implement projects in the process of teaching biological disciplines in a pedagogical university.

Analysis of theoretical and methodological literature showed that the concept of the project in the pedagogical aspect is quite ambiguous.

"Project" (from Latin word projectum from the Latin verb proicere, "before an action") as a concept belongs to the same category as the "experiment" in the natural Sciences, "consideration of the case" in law or "tactics and strategy" in the military. This concept has long ceased to be associated only with architecture or engineering activities. It is now actively used in the economy, politics and pedagogy.

S. I. Ozhegov gives the following definition of the project:

1) the developed plan of construction, the organization of something; 
2) preliminary text of a document;

3) idea, plan [4].

It is also indicated that the project is a joint activity of the teacher and students aimed at solving a complex professional problem and creating a socially significant product, and conditions for the implementation of cognitive and professional motives of students arise during this activity [5].

A number of Russian researchers (Sternberg V. N., Simonenko V. D., Zimnyaya I. A., Skvortsova I.) giving the definition of the project, emphasize the independence and activity of students; point to the need to take into account their emotional sphere; note that the project is focused on the definition of needs, the formulation of problems and the creation of situations close to reality.

Modern scientists (V. V. Guzeev, M. V. klarin, D. G. Levites, E. S. Polat, etc.) have also tried to clarify the meaning and reveal the content of the method of projects. They consider the method of projects at a qualitatively new level - as a integral learning technology that contributes to the mastery of students ' methodological knowledge, skills, as the basis for further self-education, as a means of developing abilities of students, research skills, social skills, etc. [6].

Table 1 - Element analysis of the survey results

\begin{tabular}{|c|c|c|}
\hline $\begin{array}{l}\text { Question } \\
\text { number }\end{array}$ & Elements of the content of students ' answers & $\%$ \\
\hline \multirow[t]{5}{*}{1.} & Explain the lack of participation in projects by followed reasons: & \\
\hline & the lack of time due to study & 15 \\
\hline & $\begin{array}{l}\text { The staff of the university doesn't organize, don't inform, don't encourage in participation in projects } \\
\text { and passivity of teachers }\end{array}$ & 63 \\
\hline & don't want to participate personally & 13 \\
\hline & didn't respond & 9 \\
\hline \multirow[t]{3}{*}{2.} & $\begin{array}{l}\text { The project is the implementation of scientific research, the scientific research of a certain object, the } \\
\text { defense of a scientific project }\end{array}$ & 44 \\
\hline & $\begin{array}{l}\text { The project includes the collection of information and research on a single topic, the revelation of a } \\
\text { single topic in any discipline }\end{array}$ & 38 \\
\hline & Don't know about the project concept & 18 \\
\hline \multirow[t]{4}{*}{3.} & Don't know what kind of activities include the organization of a research project & 58 \\
\hline & $\begin{array}{l}\text { The following answers were offered: "choice of topic, definition of purpose, tasks", "choice of topic, } \\
\text { presentation of topic, research on the topic", "choice of topic, collection of information on the topic", " } \\
\text { analysis, design, definition of purpose, tasks, hypotheses» }\end{array}$ & 30 \\
\hline & Activity consists firstly of drawing up the plan, the choice of object, the equipment & 8 \\
\hline & Motivation and creation of conditions for participants are necessary to organize the project & 4 \\
\hline \multirow[t]{3}{*}{4.} & Don't know what kind of activities include the implementation of a research project & 58 \\
\hline & The activity of the project is "a search, a motivation and an information gathering" & 14 \\
\hline & $\begin{array}{l}\text { The activities of the project include "research, protection, proof, achievement of the goal", "experiment, } \\
\text { joint work", "definition of the goal and objectives of the project", "control, evaluation, presentation of } \\
\text { the topic, research, conclusions", "analysis, experiment, project implementation, project completion", " } \\
\text { object research, analysis" }\end{array}$ & 28 \\
\hline \multirow[t]{2}{*}{5.} & Incorrectly defined the sequence of actions in the organization and implementation of the project & 86 \\
\hline & Correctly defined the sequence of actions in the organization and implementation of the project & 14 \\
\hline \multirow[t]{5}{*}{6.} & $\begin{array}{l}\text { The readiness for the organization and implementation of the research project is important to biology } \\
\text { teacher: }\end{array}$ & \\
\hline & to improve skills and knowledge & 52 \\
\hline & to be ready for research & 28 \\
\hline & to train children in the implementation of the project at school later & 4 \\
\hline & $\begin{array}{l}\text { Deny importance of the readiness for the organization and implementation of the research project to a } \\
\text { biology teacher owing to the fact that they are not trained to this }\end{array}$ & 16 \\
\hline 7. & $\begin{array}{l}\text { Students are ready to take part in the implementation of projects on biological disciplines at the } \\
\text { university in case of creating conditions for project implementation, training for organization and } \\
\text { implementation of project }\end{array}$ & 88 \\
\hline
\end{tabular}

P. P. Blonsky, S. T. Shatsky, V. Kumarin and others understood the method of projects in their studies as a means of:

1. comprehensive exercise of mind and development of thinking; 
2. development of creative abilities;

3. development of independence and preparation of students for self-employment;

4. to prepare students for professional activities;

5. the merger of theory and practice in training .

2. Research methods. The questionnaire survey of biology students of Abai Kazakh national pedagogical university was held out to determine their initial level of readiness for the organization and implementation of projects in biological disciplines

3. Main part. The survey was conducted in the form of open questions. The first question was to find out the participation of students in projects in an university. The second question is to determine the students ' knowledge of the concept of the project. The third question is what is the organization of the project. The fourth question relates to the knowledge of the project. The fifth question allows you to determine the students' possession of algorithm of actions in the organization and implementation of the project. The sixth question aims to clarify the importance of the readiness of a future biology teacher for the organization and implementation of the project. The purpose of the seventh question was to establish the reasons that encourage students to master the project activities.

The results of the element analysis of students' answers are given in table 1.

Conclusion. The results of the analysis of the practice of professional training of future teachers in Abai university indicate that a significant emphasis is placed on the formation of theoretical knowledge about projects and design and much less attention is paid to the formation of students' practical skills. The results of the survey showed the low readiness of students-biologists for the organization and implementation of projects and at the same time their high interest in learning project activities.

The success of the project activities of students is the basis of their creatively active well-being, the formation of their own ways of solving professional problems on their own. Students' success in the process of implementing their own project activities is a very important condition for their readiness to guide schoolchildren in project activities [7].

\section{REFERENCES}

[1]Makroekonomicheskoye obespecheniye sotsial'no-ekonomicheskogo razvitiya Kazakhstana v usloviyakh modernizatsii. Vestnik Natsional'noy Akademii Nauk Respubliki Kazakhstan. ISSN 1991-3494. Vypusk 6, №358, Almaty, 2015, S.179-185. (Mergenbayeva A.T., Urazbayeva G.ZH., Abishova A.U.) https://doi.org/10.32014/2018.2518-1467

[2] State of the Nation Address by the President of the Republic of Kazakhstan Nursultan Nazarbayev. January 31, 2017 "Third Modernization of Kazakhstan: Global Competitiveness".

[3] State of the Nation Address by the President of the Republic of Kazakhstan Nursultan Nazarbayev, January 10, 2018 "New opportunities under the fourth industrial revolution".

[4] Ozhegov, S. I. Dictionary of Russian / S. N. Ozhegov. Moscow: Russkiy yazyk, 1986. 797 p.

[5] Burtseva, E. V. Educational project as a means of motivation of foreign language studying for students of non-linguistic universities: (Eng.): Autoref. of thesis on cand. of ped. sc. degree: (13.00.02) / E. V. Burtseva; Buryat state un-ty., Ulan-Ude, 2002. $25 \mathrm{p}$.

[6] Stepanova I. M. Technology of project training as a means of formation of educational and cognitive independence of junior courses students of pedagogical universities: subject "Foreign language": Thesis on cand. of ped.sc. degree. Murmansk, 2002. $164 \mathrm{p}$.

[7] Panchuk, T. A. Formation of readiness for project activity of students of faculties of technology and entrepreneurship: Thesis on cand. of ped.sc. degree / T. A. Panchuk. Biysk, 2004. 184 p.

\section{Г.У. Абишова ${ }^{1}$ Р. Аманжолов ${ }^{1}$, Б.Н. Мынбаева ${ }^{1}$, Д.И. Ибрагимова ${ }^{2}$}

\footnotetext{
${ }^{1}$ Казахский национальный педагогический университет имени Абая, Алматы, Казахстан;

${ }^{2}$ Международный казахско-турецкий университет имени Х.А.Яссави, Туркестан, Казахстан
}

\section{ГОТОВНОСТЬ СТУДЕНТОВ-БИОЛОГОВ К ОРГАНИЗАЦИИ И ВЫПОЛНЕНИЮ ПРОЕКТОВ В ВУЗЕ}

Аннотация. На сегодняшний день реформы казахстанской системы образования направлены на пересмотр системы требований к знаниям, умениям, способностям и личностным качествам педагога с позиции компетентностного подхода. С целью обучить студентов навыкам и умениям, необходимым для конкурентоспособности в мировой экономике необходимо внедрение проектного обучения или метода 
проектов. Готовность студентов-биологов к организации и выполнению проектов является условием для успешного осуществления профессиональной деятельности, поскольку умение проектировать способствует успешному решению профессиональных задач. Обладая огромными потенциальными возможностями, проектная деятельность позволяет повысить качество биологической подготовки будущих профессионалов, воспитать личность на принципах единства учебного творчества с реальной практической деятельностью.

В данной статье для подтверждения актуальности данного исследования и выяснения состояния исходной готовности студентов к организации и выполнению проектов в вузе проведено анкетирование среди студентов-бакалавров. Результаты анкетирования свидетельствуют о низкой готовности студентовбиологов к организации и выполнению проектов вместе с тем их высокой заинтересованностью к обучению проектной деятельности. Следовательно, проектную деятельность студентов необходимо формировать как в ходе специально организованного обучения, так и в рамках учебных предметов.

Ключевые слова. Проект, метод проектов, проектная деятельность, готовность, организация и выполнение проектов, анкетирование.

\section{Г.У.Абишова ${ }^{1}$, Р.Аманжолов ${ }^{1}$, Б.Н.Мынбаева ${ }^{1}$, Д.И.Ибрагимова ${ }^{2}$ \\ ${ }^{1}$ Абай атындағы қазақ ұлттық педагогикалық университеті, Алматы, Қазақстан; \\ ${ }^{2}$ Қ.А.Ясауи атындағы халықаралық қазақ-түрік университеті, Алматы, Қазақстан \\ ЖОО-да БИОЛОГ-СТУДЕНТТЕРДІҢ ЖОБАЛАРДЫ ҰЙЫМДАСТЫРЫЛУЫ МЕН ОРЫНДАЛУЫНА ДАЯРЛЫҒЫ}

Аннотация. Бүгінгі таңда қазақстандық білім беру жүйесінің реформалары құзыреттілік көзқарас тұрғысынан педагогтың біліміне, шеберлігіне, қабілетіне және жеке қасиеттеріне қойылатын талаптар жүйесін қайта қарауға бағытталған. Студенттерді әлемдік экономикадағы бәсекеге қабілетті ету үшін қажетті дағдылар мен іскерлікке үйрету мақсатында жобалық оқытуды немесе жобалар әдісін енгізу қажет. Биологстуденттердің жобаларды ұйымдастыруға және орындауға дайындығы кәсіби қызметті табысты жүзеге асыру үшін шарт болып табылады, өйткені жобаларды білу кәсіби міндеттерді табысты шешуге ықпал етеді. Үлкен әлеуетті мүмкіндіктерге ие бола отырып, жобалау қызметі болашақ мамандардың биологиялық дайындығының сапасын арттыруға, нақты практикалық қызметпен оқу шығармашылығының бірлігі қағидаттарында тұлғаны тәрбиелеуге мүмкіндік береді.

Бұл мақалада осы зерттеудің өзектілігін растау және студенттердің ЖОО-да жобаларды ұйымдастыруға және орындауға бастапқы дайындық жағдайын анықтау үшін бакалавр-студенттер арасында сауалнама жүргізілді. Сауалнама нәтижелері биолог-студенттердің жобаларды ұйымдастыруға және орындауға дайындығының төмендігін, сонымен бірге олардың жобалық қызметті оқытуға деген қызығушылығының жоғары екендігін көрсетеді. Демек, студенттердің жобалық қызметін арнайы ұйымдастырылған оқыту барысында да, оқу пәндері аясында да қалыптастыру қажет.

Түйін сөздер. Жоба, жоба әдісі, жобалау қызметі, дайындық, жобаларды ұйымдастыру және орындау, сауалнама жүргізу.

Сведения об авторах:

Абишова Гулжан Уринбасаровна - докторант Казахского национального педагогического университет имени Абая. abish_gul@mail.ru;

Аманжолов Рустам - докторант Казахского национального педагогического университет имени Абая. amanzholov@mail.ru;

Мынбаева Бахыт Насыровна - доктор биологических наук, профессор кафедры «Биологии» Казахского национального педагогического университет имени Абая. mynbaeva@mail.ru;

Ибрагимова Даметкен Ибадуллаевна - преподаватель кафедры Биологии Международного казахско-турецкого университета имени Ходжи Ахмеда Ясави. ibragimova@mail.ru 


\section{МАЗМҰНЫ}

Беспаева Р.С., Бугубаева Р.О., Мануэль Ф. Грела2. Көрсеткіштердің теңдестірілген жүйесі негізінде Щучинск-Бурабай курорттық аймағын дамытудың кешенді стратегиясын қалыптастыру ................................................................................ 5

Аюпова 3.К., Құсайынов Д.Ө.Азаматтық процесстерді жетілдірудегі интеграцияның кейбір қырлары...................... 13

Құсайынова А. А., Вальдемар Козловски, Геращенко И. П.Қазақстан республикасындағы міндетті әлеуметтік сақтандырудың қаржылық-құқықтық тетіктерінің ерекшеліктері.

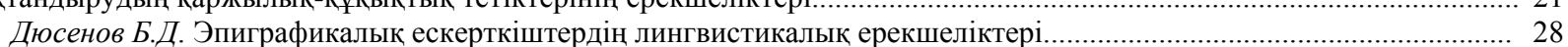

Джумадилова Ш.Г., Атабай Б.Ж. Қазақстандағы халықтың жинақтарының динамикасы......................................... 33

Карабалина А.А., Альситова А. Б., Кереймаганбетова Ж.Н., Абишева Н. М. Құндылық - рухани-адамгершілік

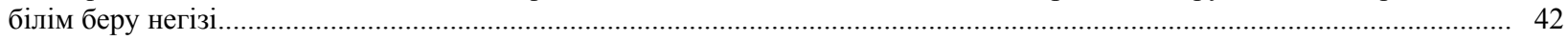

Кенжебаева Д.К., Өрмөрза Б. Ғ., Дашгин Махаммадли. Қазақстандық заманауи жастардың құндылығы............. 51

Нурманова А.Ш., Медерова Д.Е., Дюсенов Б.Д. «Бөкейхан әулетінің талдыбейіт қорымы» эпиграфикалық ескерткіштері тарихи дереккөз ретінде.

Кыдырова Ж.Ш., Онласынов Е.З., Абишова А.У., Шадиева А.А. Оңтүстік Қазақстан облысы сүт және сүт өнімдері нарығындағы жағдайды зерттеу ......

Абимова Г.У., Аманжолов Р., Мынбаева Б.Н., Ибрагимова Д.И. ЖОО-да биолог-студенттердің жобаларды

ұйымдастырылуы мен орындалуына даярлығы.......

Балтабаева А.Ю., Ризаходжаева Г. Мәдени интеграция үдерісіндегі жібек жолының феномені............................... 9

Бурганова Р.И., Абдугалина С.Е., Туякова А.Е. Студенттерге бағытталған білім беру арқылы білім сапасын

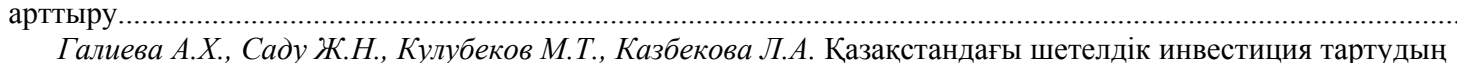

институционалдық жағдайын (талаптарын) бағалау..

Джалилов 3.Г., Батырхан Б.Ш. ХX ғ. екінші жартысындағы шетелдік исламтанушылардың ислам және саясат

туралы теориялық дискурсы.......

Джумабекова А.Т., Канатова А.Ж. Қаржылық ынтымақтастық жағдайларындағы Қазақстан республикасының

ұлттық банкінің өткізу механизмінің өзгеруі......

Дүйсен Г. М., Айтжанова Д. А. Қазақстан және Орталық Азия елдеріндегі көші-қон процесстері дамуының мәселелері мен ерекшеліктері

Есендұлова М.Н. Қазақстандағы « Қиын балаларды» оңалтудың және әлеуметтендірудің психологиялық ерекшеліктері

Жакишева К.М., Жуманова Д.Т., Мукашева Г.М. Экономиканың аграрлық секторының тұрақты дамуына арналған ауыл шаруашылық кәсіпорындарының қаржылық шарттарын мониторингінің рөлі.....

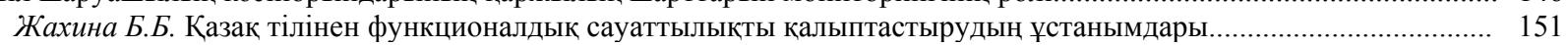

Идресова У.Х., Садуахасова 3.Ж., Муханова А.Т. Криминалистика....................................................................... 156

Савельева В. В. Қазақстандағы кредит технологиясын пайдалану және дамуының тарихи және педагогикалық базасы.

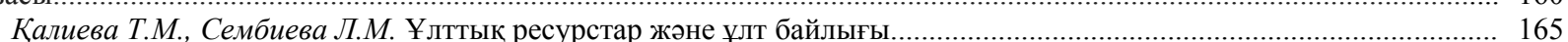

Каримова Р.У., Хаджиева Г.У. ҚХР Ұлттық саясаты контексіндегі ШҰАА-ның этносаяси және әлеуметтікэкономикалық трансформациясы мәселесі.

Керімбек Г., Молдашбаева Л., Джрауова Қ., Ажмухамедова А., Мизанова А. Қазақстан республикасының

республикалық бюджетіне түсетін салық түсімдерінің көрсеткіштерін талдау және бағалау.....

Жолдасбекова С.А., Парманкулова П.Ж., Асаналиев М.К. Мүмкіндігі шектеулі балаларды дамытудағы ұлттық ойындар

Молдакенова Е.К., Байгабулова К.К., Онаева Б.Т. БҚО-да инновациялық үрдістерді басқарудың аймақтық

аспектілігі жүйесінің дамудың жолдары.

Мұратова Г.К., Шаушенова А.Г., Жумасеитова С.Д., Онұварбаева М.Б.Білім беру үрдісінде бұлттық

технологияларын қолдану......

Несіпбеков E. Н., Аппакова Г.Н. Кәсіпорынның инвестициялық портфелін қалыптастырудың теориялық

Нургабылов М.Н., Барлыков Е.К., Егембердиева С.М. ҚР есеп өнеркәсібінің дамуының басқаруының трендсі....... 220

Нурымбетов Т.Я., Абишова А.У., Уразбаева Г.Ж., Кыдырова Ж.Ш., Байнеева П.Т., Абишо Н.У. Модернизациялық

жағдайындағы қр халқын әлеуметтік қолдауының басымдықтары.....

Рахимова С. А., Тургумбекова М. М. Қазақстан республикасындағы шағын және орта бизнестіңмемлекеттік қолдау

бағдарламалары және олардың тиімділігін жүзеге асыру шаралары.......................................................................... 233

Руденко Е.И. Орталық пен Оңтүстік Азия мемлекеттері арасындағы ұғынудың бұрмалануы - «Жұмсақ күш»

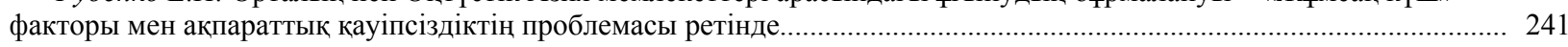

Тохтабаева Ш. Қазына-сандық.......................................................................................................... 251

Утепкалиева К.М., Сабирова Р.К., Кенбаева Г.У. Мұнай-газ секторындағы мемлекеттік-жеке серіктестікті дамыту

Мыңбаев Д. Е. Банкте басқару есебін ұйымдастыру тұжырымдамасы...

Султанова Г.С. Жаңа формацияның экономисі - бакалаврдың кәсіби құзыреттілігін қалыптастырудың

Шаяхметова А.А. Университет жағдайында инклюзивті білім беру үшін педагогтарды оқыту....... 


\section{СОДЕРЖАНИЕ}

Беспаева Р.С., Бугубаев Р.О., Мануэль Ф. Грела. Формирование комплексной стратегии развития ЩучинскоБоровской курортной зоны на основе сбалансированной системы показателей. Аюпова 3.К., Кусаинов Д.У., Уинстон Наган. Некоторые грани интеграции в совершенствовании гражданского процесса.

Кусаинова А.А., Козловски Вальдемар, Геращенко И.П. Обзор некоторых особенностей финансово-правового механизма обязательного социального страхования в республике Казахстан......

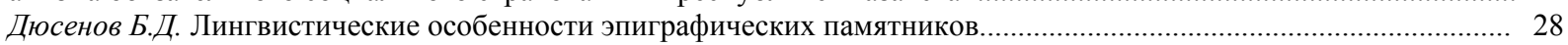

Джумадилова Ш.Г., Атабай Б.Ж.Динамика сбережений населения в Казахстане................................................... 33

Карабалина А.А., Альситова А. Б., Кереймаганбетова Ж.Н., Абишева Н. М. Ценность как базовая основа духовнонравственного образования.

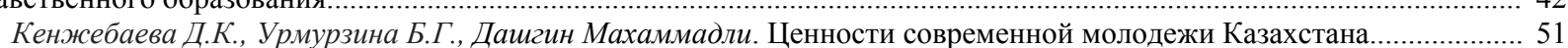

Нурманова А.Ш., Медерова Д.Е., Дюсенов Б.Д. Эпиграфические памятники «Некрополи талдыбейит династии

Бокейхановых» как исторический источник.

Кыдырова Ж.Ш., Онласынов Е.З., Абишова А.У., Шадиева А.А.Исследование ситуации на рынке молока и молочной продукции южно-казахстанской области

Абишова Г.У., Аманжолов Р., Мынбаева Б.Н., Ибрагимова Д.И. Готовность студентов-биологов к организации

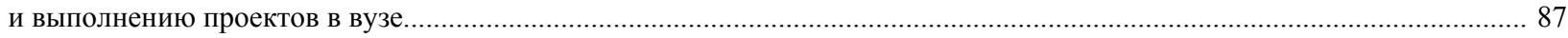

Балтабаева А.Ю., Ризаходжаева Г. Феномен великого шелкового пути в процессе культурной интеграции............... 91

Бурганова Р.И., Абдугалина С.Е., Туякова А.Е. Повышение качества образования посредством

студентоцентрированного обучения...

Галиева А.Х., Саду Ж.Н., Кулубеков М.Т., Казбекова Л.А. Оценка институциональных условий привлечения

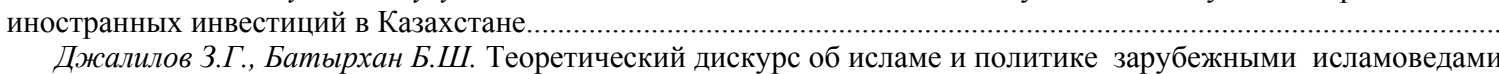
второй половины ХX в.

Джумабекова А.Т., Канатова А.Ж. Трансформация трансмиссионного механизма национального банка республики

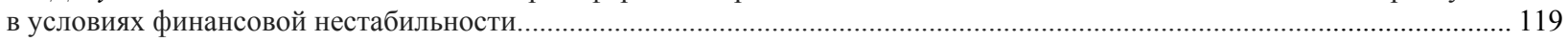

Дуйсен Г.М., Айтжанова Д.А. Проблемы и особенности развития миграционных процессов в Казахстане

и странах Центральной Азии.

Есенгулова М.Н. Психологические особенности реабилитации и социализации "Трудных подростков"

в Казахстане".

Жакишева К.М., Жуманова Д.Т., Мукашева Г.М.Роль мониторинга финансового состояния сельскохозяйственных

предприятий в обеспечении устойчивого развития аграрного сектора экономики.........................................................146

Жахина Б.Б. Принципы формирования функциональной грамотности казахского языка.......................................... 151

Идресова У.Х., Садуахасова 3.Ж., Муханова А.Т. Криминалистика......................................................................... 156

Савельева B.B. Исторические и педагогические основы формирования и разработки кредитной технологии

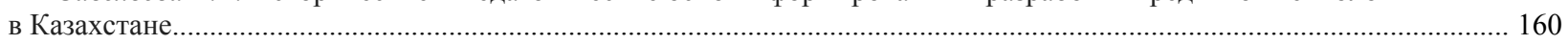

Калиева Т.М., Сембиева Л.М. Национальные ресурсы и богатство нации.................................................. 165

Каримова Р.У., Хаджиева Г.У. К вопросу об этно-политической и социально-экономической трансформации

СУАР в контексте национальной политики КНР

Керимбек Г., Молдашбаева Л., Джрауова Қ., Ажмухамедова А., Мизанова А. Анализ и оценка показателей

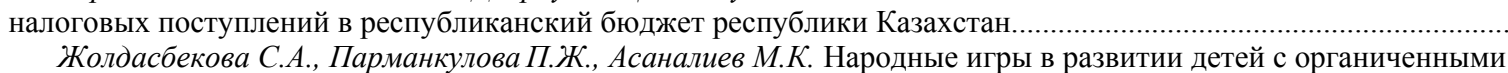

Жолдасбекова С.А., Парманкулова П.Ж., Асаналиев М.К. Народные игры в развитии детей с органиченными

Молдакенова Е.К., Байгабулова К.К., Онаева Б.Т.Пути развития системы регионального аспекта управления

инновационными процессами в АПК.

Муратова Г.К., Шаушенова А.Г., Жумасеитова С.Д., Онгарбаева М.Б. Применение облачных технологий

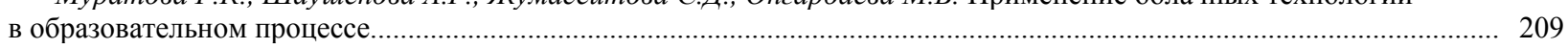

Несипбеков Е.Н., Аппакова Г.Н. Теоретические аспекты формирования инвестиционного портфеля предприятия. 214

Нургабылов М.Н., Барлыков Е.К., Егембердиева С.M. Тенденции управления развитием мясоперерабаты-

вающей отрасли в РК.

Нурымбетов Т.Я., Абишова А.У., Уразбаева Г.Ж., Кыдырова Ж.Ш., Байнеева П.Т., Абишов Н.У. Приоритеты

социальной поддержки населения РК в условиях модернизации................................................................................. 22

Рахимова С. А., Тургумбекова М. М. Программы государственной поддержки мсб в республике Казахстан и меры

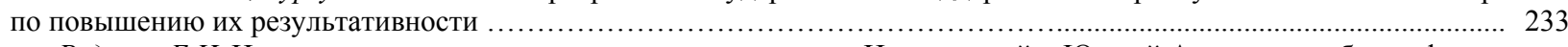

Руденко Е.И. Искаженность восприятия между государствами Центральной и Южной Азии как проблема фактора

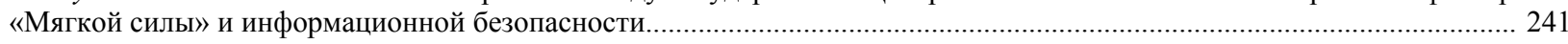

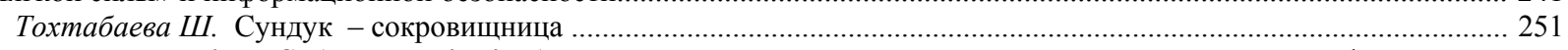

Утепкалиева К.М., Сабирова Р.К., Кенбаева Г.У.Развитие государственно-частного партнерства в нефтегазовой

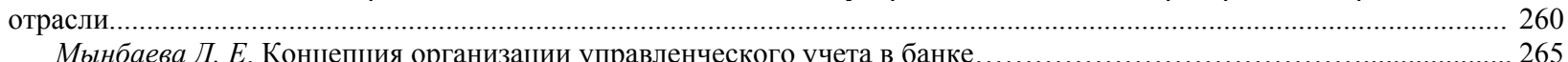

Мынбаева Д. Е. Концепция организации управленческого учета в банке...........................................2.
Султанова Г.С. Педагогические аспекты формирования профессиональных компетенций бакалавра - экономиста

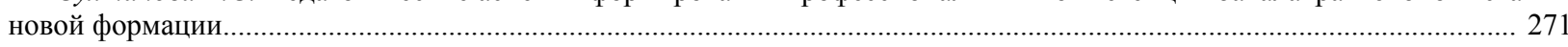

Шаяхметова А.А. О подготовке педагогических кадров к инклюзивному образованию в условиях вуза................ 277 


\section{CONTENTS}

Bespayeva R.S., Bugubayeva R.O., Manuel F. Grela. Formation of the complex strategy for development of the Schuchinsk-

Burabay resort area based on the balanced system of indicators.

Ayupova Z.K., Kussainov D.U., Winston Nagan. Some facets of integration in themodernization ofthe civil process..............13

Kussainova A.A., Kozlowski Waldemar, Gerashchenko I.P. The review of some features of the financial legal mechanism of obligatory social insurance in the republic of Kazakhstan...

Dyussenov B.D. Linguistic features of epigraphic monuments................................................................................ 28

Jumadilova Sh.G., Atabay B.Zh. Dynamics of the population savings in Kazakhstan.......................................................... 33

Karabalina A.A., Alsitova A.B., Kereimaganbetova Zh.N., Abisheva N.M. The values as critical factor of moral education... 42

Kenzhebayeva D.K., Urmurzina B.G., Dashqin Mahammadli. The modern youth values in Kazakhstan............................. 51

Nurmanova A.S., Mederova D.E., Dyussenov B.D. "Bokeykhanov dynasty taldybeyit necropolis" epigraphic monuments

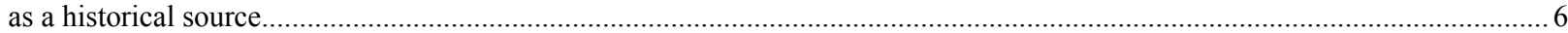

Kydyrova Zh.Sh., Onlasynov E.Z., Abishova A.U., Shadieva A.A.Research of the situation in the market of milk and dairy

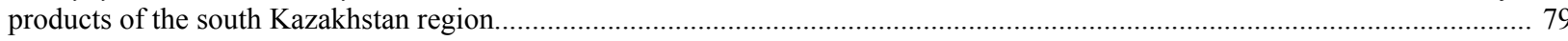

Abishova G.U., Amanzholov R.A., Mynbayeva B.N., Ibragimova D.I. Readiness of students-biologists for the organization

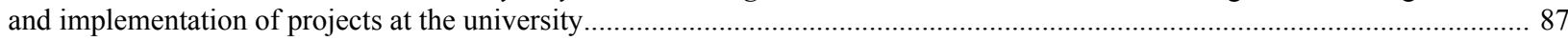

Baltabayeva A.Y., Rizakhojayeva $G$. The phenomenon of the great silk road in the cultural integration process................... 91

Burganova R.I., Abdugalina S.E., Tuyakova A.E. Improving the quality of education through student-centered education... 102

Galiyeva A.Kh., Sadu Zh.N., Kulubekov M.T., Kazbekova L.A. Assessment of the institutional terms of the foreign

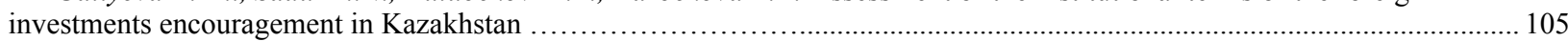

Dzhalilov Z.G. Theoretical discourse on islam and politics in foreign humanism of the second half of 20th century.......... 112

Dzhumabekova A.T., Kanatova A.ZH. Transformation of the transmission mechanism of the national bank of the republic

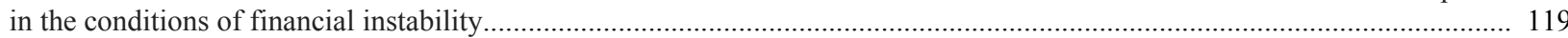

Suleimenov R.B. Problems and features of the development of migration processes in Kazakhstan and Central Asia.......... 124

Yesengulova M.N. Psychological aspects of reintegration and resocialization of "Trouble" adolescents in Kazakhstan....... 134

Zhakisheva K.M., Zhumanova D.T., Mukasheva G.M.The role of monitoring the financial condition of agricultural

enterprises in ensuring sustainable development of the agrarian sector of the economy......................................................... 146

Zhakhina B.B. Principles of functional literacy formation of the kazakh language....................................................... 151

Idresova U.Kh., Saduahasova Z.Zh., Mukhanova A.T. Criminalistics............................................................................. 156

Savelyeva $V . V$. Historicalandpedagogical bases of formation and development of credit technology in Kazakhstan........... 160

Kaliyeva T.M., Sembiyeva L.M. National Resources and national wealth.................................................................. 165

Karimova R., Hajiyeva G. Examining ethno-political and SOCIO-economic transformation of the xinjiang uyghur

autonomous region in the context of the PRC national policies........................................................................................ 176

Kerimbek G., Moldashbayeva L., Jrauova K., Azhmukhamedova A., Misanova A. Analysis and evaluation of reduction

of tax recovery of the republic of kazakhstan on the budget of the republic of Kazakhstan................................................. 185

Zholdasbekova S.A., Parmankulova P.Zh., Assanaliyev M.K. Folk games in the education of children with physical, mental and sensory disturbances..

Moldakenova E.K., Baygabulova K.K., Onaeva B.T. Ways of development of the system of the regional aspect of managing innovative processes in the APC.

Muratova G.K., Shaushenova A.G., Zhumassseitova C.D., Ongarbayeva M.B. Application of cloud technologies in the educational process......

Nurgabylov M.N., Barlikov E.K., Egemberdieva S.M. Trends of management of the development of meat processing industry in RK

Nurymbetov T.Ya., Abishova A.U., Urazbaeva G.Zh., Kydyrova Z.Sh., Baineeva P.T., Abishov N.U. Priorities of social support of the population of republic of Kazakhstan in the conditions of modernization........

Rakhimova S. A., Turgumbekova M. M. Programs of government support for sme in the republic of Kazakhstan and measures to enhance their efficiency.....

Rudenko Ye.I. Misperception between the states of Central and South Asia as a 'Soft power' and information security issue...

Tokhtabayeva Sh. Zh. Treasure-chest.

Utepkalieva K.M., Sabirova R.K., Kenbaeva G.U.Development of public private partnership approach in oil and gas

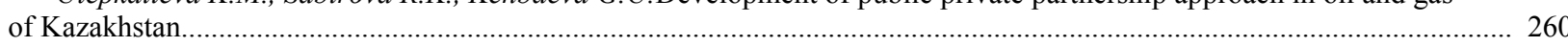

Mynbayeva D.E. Concept of organization of management accounting in bank ........................................................... 265

Sultanova G. S. Pedagogical aspects of formation of professional competence of the bachelor-economist of the new formation

Shayakhmetova A.A. On the training of teaching staff for inclusive education under the conditions of higher education institution. 


\section{PUBLICATION ETHICS AND PUBLICATION MALPRACTICE IN THE JOURNALS OF THE NATIONAL ACADEMY OF SCIENCES OF THE REPUBLIC OF KAZAKHSTAN}

For information on Ethics in publishing and Ethical guidelines for journal publication see http://www.elsevier.com/publishingethics and http://www.elsevier.com/journal-authors/ethics.

Submission of an article to the National Academy of Sciences of the Republic of Kazakhstan implies that the work described has not been published previously (except in the form of an abstract or as part of a published lecture or academic thesis or as an electronic preprint, see $\mathrm{http} / / / \mathrm{www} . e l s e v i e r . c o m / p o s t i n g p o l i c y)$, that it is not under consideration for publication elsewhere, that its publication is approved by all authors and tacitly or explicitly by the responsible authorities where the work was carried out, and that, if accepted, it will not be published elsewhere in the same form, in English or in any other language, including electronically without the written consent of the copyrightholder. In particular, translations into English of papers already published in another language are not accepted.

No other forms of scientific misconduct are allowed, such as plagiarism, falsification, fraudulent data, incorrect interpretation of other works, incorrect citations, etc. The National Academy of Sciences of the Republic of Kazakhstan follows the Code of Conduct of the Committee on Publication Ethics (COPE), and follows the COPE Flowcharts for Resolving Cases of Suspected Misconduct (http://publicationethics.org/files/u2/New_Code.pdf). To verify originality, your article may be checked by the originality detection service Cross Check http://www.elsevier.com/editors/plagdetect.

The authors are obliged to participate in peer review process and be ready to provide corrections, clarifications, retractions and apologies when needed. All authors of a paper should have significantly contributed to the research.

The reviewers should provide objective judgments and should point out relevant published works which are not yet cited. Reviewed articles should be treated confidentially. The reviewers will be chosen in such a way that there is no conflict of interests with respect to the research, the authors and/or the research funders.

The editors have complete responsibility and authority to reject or accept a paper, and they will only accept a paper when reasonably certain. They will preserve anonymity of reviewers and promote publication of corrections, clarifications, retractions and apologies when needed. The acceptance of a paper automatically implies the copyright transfer to the National Academy of sciences of the Republic of Kazakhstan.

The Editorial Board of the National Academy of sciences of the Republic of Kazakhstan will monitor and safeguard publishing ethics. 
Правила оформления статьи для публикации в журнале смотреть на сайте:

\section{www:nauka-nanrk.kz}

\section{social-human.kz}

Редакторы М.С. Ахметова, Т.А. Апендиев, Д.С. Аленов

Верстка на компьютере А.М. Кульгинбаевой

Подписано в печать 08.12.2018

Формат 60x881/8. Бумага офсетная. Печать - ризограф.

17,7 п.л. Тираж 500. Заказ 6.

Национальная академия наук $Р К$

050010, Алматы, ул. Шевченко, 28, т. 272-13-18, 272-13-19 